\title{
A Note on Usage
}

\section{Names and Orthography}

Orthographic flexibility (or inconsistency, one might say) rules the Latin records used in this study. Even within one document, a single person's name may be identified using different spellings, for example: Kali, Cali, Calli, and Kalli. In addition, some of these individuals also have Hebrew names apparent in the Jewish sources. These names are usually related to, but different than, their Latinate names and must also be rendered consistently for this study. In recording names in the text, therefore, I have standardized the spelling either by using the common English spelling or by choosing a single orthography that reflects the most common usage (for example, Cali). I have rendered Isaac, Judah, and Joseph following standard English usage. The HellenizedLatinate version of Elijah used so commonly in these sources has many spellings: Liachus, Ligiachus, Lingiachus, Lighiachus, and so forth. I have chosen the Italianate Liacho, which reflects how the name might have been pronounced. While some men named Elijah in Hebrew were called Liacho in the vernacular, many others were called Elia. This distinction remains consistent in the ducal records, and I have retained it according to that information.

When Hebrew is transliterated, the $\pi$ has been rendered $h$ and the $\supset$ has been rendered kh.

\section{Dating}

Venice began its year on I March. The Jewish calendar follows a modified lunar calendar with a new year beginning in the autumn at the start of the month of Tishrei. For ease of understanding, I have changed all Venetian and Jewish dates to the familiar Julian calendar (solar, Christian, beginning the year with I January) unless otherwise specified. Thus, for example, a ducal 
record marked 4 February 1439 will be rendered 4 February 1440 in this study, since the I439 dating is according to the Venetian calendar, which did not begin the new year until I March.

\section{Coinage and Currency}

In Crete during this period, the money of account was the hyperperon (a unit borrowed from the Byzantine coinage system), calculated in terms of the Venetian grosso. One hyperperon (in Venetian, a perpero) equaled twelve Venetian grossi. Twelve grossi also equaled about twenty-six soldi. ${ }^{1}$ Notarial and ducal records almost always mention prices and fines in Cretan hyperpera, with smaller fractions of hyperpera calculated in grossi. Cretan hyperpera should not be confused with the hyperpera of Constantinople, nor should this money of account be confused with an actual coin. There was no mint in Crete during this period. ${ }^{2}$ Taqqanot Qandiya mentions ducats (in this period, the gold ducat coin equaled about 2 Cretan hyperpera) ${ }^{3}$ and florins, in addition to grossi, suggesting the range of coins and moneys of account used in transactions. ${ }^{4}$ It also mentions dinarim, a general currency designation in Hebrew that probably refers to hyperpera. ${ }^{5}$

\section{Abbreviations and Archival Citations}

$T Q=$ Elias Artom and Umberto Cassuto, Taqqanot Qandiya u'Zikhronoteha (Statuta Iudaeorum Candiae eorumque Memorabilia). Jerusalem: Mekize Nirdamim, 1943.

Material from the Archivio di Stato in Venice (ASV) is rendered according to archive (ASV), series (usually Notai di Candia or Duca di Candia), busta (envelope-box) number, register number (that is to say, folder within the busta), and folio number. I then follow with the date of the entry in parentheses. For example: ASV Duca di Candia, b. 26, r. 8, fol. 7v (I October I437). 


\section{Colonial Justice and the Jews of Venetian Crete}




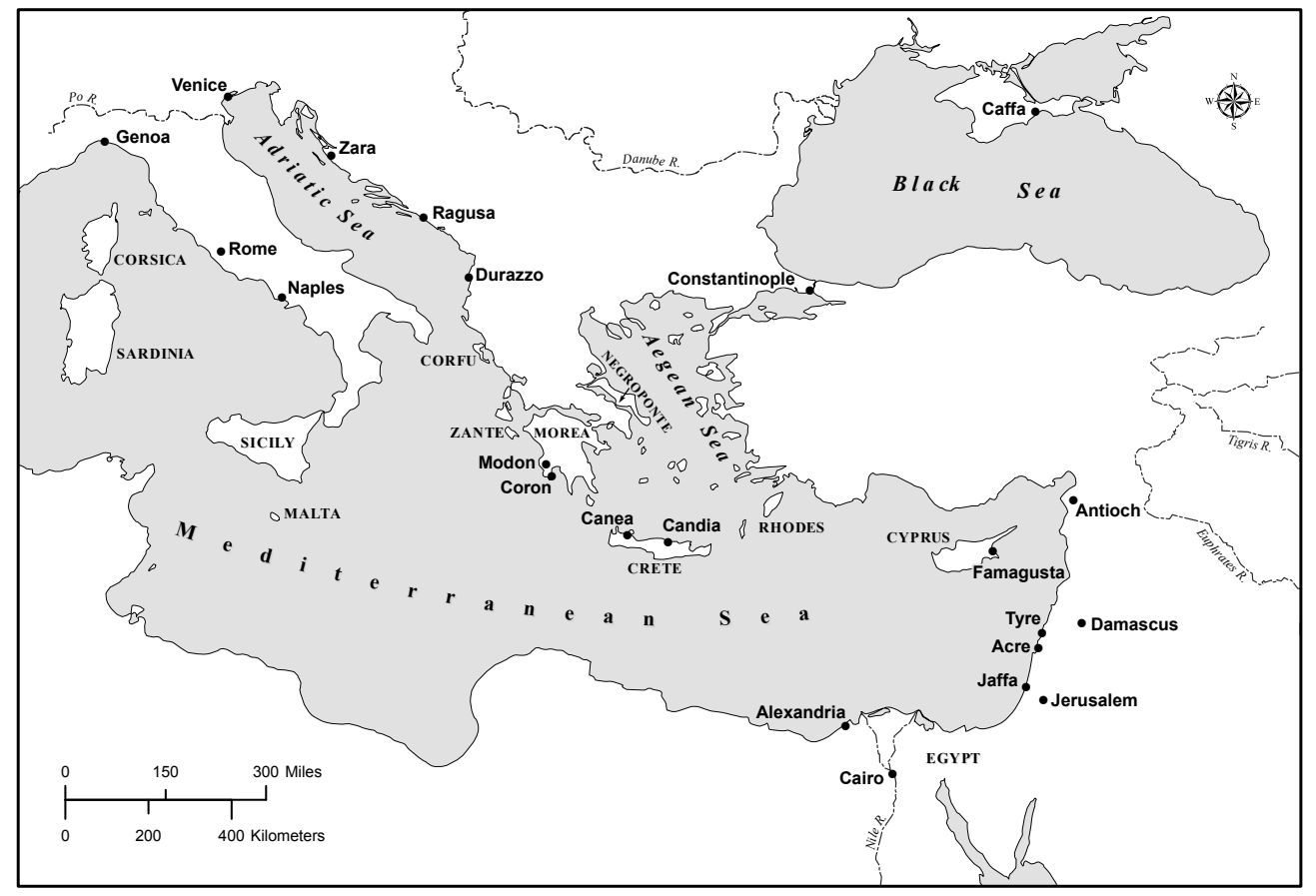

Map 1. The eastern Mediterranean in the late Middle Ages. 